\title{
Bees as Bioindicators of Environmental Pollution with Metals in an Urban Area
}

\author{
Elżbieta Skorbiłowicz'1, Mirosław Skorbiłowicz ${ }^{1 *}$, Izabela Cieśluk¹ \\ 1 Department of Technology in Engineering and Environmental Protection, Faculty of Civil and Environmental \\ Engineering, Bialystok University of Technology, ul. Wiejska 45A, 15-354 Bialystok, Poland \\ * Coresponding author's e-mail: m.skorbilowicz@pb.edu.pl
}

\begin{abstract}
The commonness of metal contamination, even at considerable distances from industrial centers and intensively used economic areas, has become the interest of many researchers. The issue of evaluating the state of the environment with the help of living organisms has become a very important part in the control of the natural environment. Honey bee (Apis mellifera L) is a good bioindicator as it is inextricably linked to the natural environment in which it lives. The aim of the research, and at the same time the main assumption of the study, was to evaluate the effectiveness of honeybees (Apis mellifera $L$ ) as bioindicators for the presence of $\mathrm{Cu}, \mathrm{Cr}, \mathrm{Zn}, \mathrm{Mn}, \mathrm{Fe}$ in the urban area (example of Bialystok city). The study includes pilot studies covering three sampling periods (March, June and September 2015). Analyses of metals were made by ASA method. The results showed the presence of $\mathrm{Cu}, \mathrm{Cr} \mathrm{Zn}$, $\mathrm{Mn}$ and $\mathrm{Fe}$ in all bees samples. An increased content of $\mathrm{Cr}$ in bees was also found, which may be the result of the presence of this element in the environment (air, soil, water, plants, pollen) and in the impregnation agent applied to protect wooden elements of the bee hive. The research showed seasonal variation of metals in bees bodies. The main sources of studied metals in bee samples seem to be motorization, industry, and municipal economy within the urban area. Statistical calculations showed a common origin of majority of studied metals. Bee studies for metals contents can be an important element of a bio-monitoring of changing natural environment as a consequence of anthropogenic activity.
\end{abstract}

Keywords: bees, bioindicators, pollution, heavy metals.

\section{INTRODUCTION}

The commonness of metal contamination, even at considerable distances from industrial centers and intensively used economic areas, has become the interest of many researchers [Ciszewski and Aleksander-Kwaterczak 2015]. Metals present in the natural environment can come from both natural and anthropogenic sources. Natural sources of metals include weathering of rocks, volcanic eruptions, and processes of soil formation. Anthropogenic sources of metals are discharges of municipal and industrial wastewater, mining and metallurgical industry [Bojakowska 1995], road transport [Kaniuczak et al. 2003], agriculture [Klavins et al. 2000], and dust from urban streets [Niedzwiedzki et al. 2000]. The sources related to human activities are a major cause of pollution and the presence of met- als in the environment. Excessive amounts of toxic elements accumulate in the environment and get into organisms of plants and animals. Harmful effects of metals on living organisms is a major environmental problem [Skorbilowicz 2012]. Bioindication is one of the oldest methods of assessing the state of the natural environment [Liu et al. 2009]. Issues of the environment state assessment by living organisms have become a very important sector in the control of the natural environment [Roman 2010]. The use of biological indicators to estimate the level of environmental pollution and their impact on the environment is relatively broad. Criteria for selecting and using the appropriate living organisms as bioindicators are:

- an ability to accumulation (or selection of specific compounds),

- occurrence in large populations, 
- their presence cannot be limited to only a single habitat,

- ease of identification and representative sampling,

- samples should be easy for chemical analysis [Kabata Pendias and Pendias 1999].

Honey bee (Apis mellifera $\mathrm{L}$ ) is a species that meets the above criteria and is a good bioindicator, its existence is inextricably linked with the environment it lives [Sadeghi et al. 2012, Steen et al. 2012]. Bees are exposed to numerous contaminants during feeding, their body hair can easily adhere pollutants from the air and during pollen and nectar collection from flowers or through water [Ruschioni et al. 2013]. Bee is increasingly being used to monitor the environmental pollution with metals in rural and urban studies [Porrini et al. 2003, Madras-Majewska and Jasiński 2003, Eremia et al. 2010, Zhelyazkowa 2012, Steen et al. 2016]. According to Roman [2003], bee staying in the area contaminated with heavy metals will largely accumulate part of the impurities in its body. The bee exposure to food with a high content of $\mathrm{Fe}, \mathrm{Mn}, \mathrm{Zn}, \mathrm{Cu}, \mathrm{Ni}, \mathrm{Co}$, and $\mathrm{Pb}$, even in the acceptable range, causes disturbances in cellular defense reactions [Buczek et al. 2008]. An additional reason for the increase in elements concentrations, e.g. toxic in the bee body, is cleansing the raw honey material in the crop from part of the impurities during its processing into honey, which are consequently accumulated in its tissues [Roman 2003].
The subject of the work was a pilot study involving three sampling periods (March, June, and September 2015), and the aim of the research and also the main objective of the work was to evaluate the usefulness of honey bees (Apis mellifera $\mathrm{L})$ as bioindicators of $\mathrm{Cu}, \mathrm{Cr}, \mathrm{Zn}, \mathrm{Mn}, \mathrm{Fe}$ presence in an urban area (example of Bialystok city).

\section{METHODS}

Apiary, in which samples were collected, is located on the outskirts of Bialystok city in Dojlidy residential area. It has about 100 bee families. A short distance from the apiary, there is the Solnicki forest, Krywlany airport, allotment gardens, Dojlidy ponds, industrial areas (print shops, plastics factory jigs and fixtures, factory of plywood and a large food company Białystok Brewery), communications tracks (roads in housing estates and domestic road No 19), as well as other southeastern parts of Bialystok city (Figure 1).

The bees samples were collected in three periods: March, June, and September 2015. The choice of the sampling was closely associated with the seasons and different activity of insects. Bees landing on the board at the hive entrance were packed in sterile plastic containers (about 100 insects each). Collected bees have been killed by freezing at $-20^{\circ} \mathrm{C}$, and then dried at 40 ${ }^{\circ} \mathrm{C}$. Subsequently, each of the sample was separately ground and thoroughly mixed to make them homogenous. Such prepared samples were

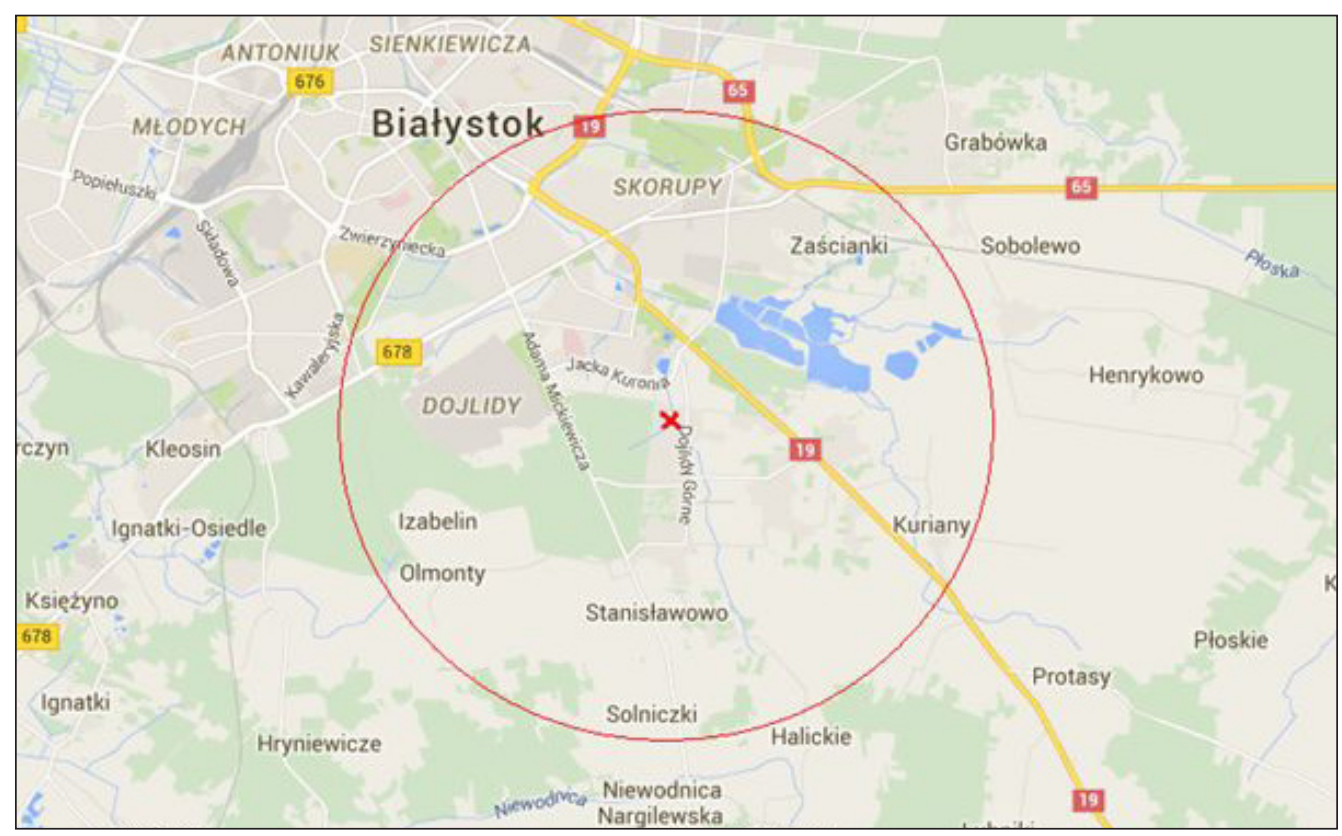

Figure 1. The location of apiary (red circle indicates a probable range of test bees flight) 
weighed $(1 \mathrm{~g})$ and digested in aqua regia $\left(9 \mathrm{~cm}^{3}\right.$ $\mathrm{HCl}$ plus $3 \mathrm{~cm}^{3} \mathrm{HNO}_{3}$ ) in the sealed microwave system ETHOS EASY. Digested samples were subject to determine the following metals: $\mathrm{Cu}$, $\mathrm{Cr}, \mathrm{Zn}, \mathrm{Mn}$, and Fe. Determinations were carried out by means of atomic absorption spectrometry technique (AAS) applying Thermo Scientfic CE 3000 Series.

The results of the research have been statistically processed. The normality tests of the results were performed, yet they did not show their normal distributions. Therefore, the analysis used three non-parametric tests of significance for independent samples: Wald-Wolfowitz, Kolmogorov-Smirnov, and U Mann-Whitney to verify the significance of differences between sampling periods at the level of $p<0.05$. To demonstrate the relationship between data, the Spearman rank-order nonparametric correlation at the level of $p<0.05$ was applied. Calculations were performed using the statistical software StatSoft Statistica 12.

\section{RESULTS AND DISCUSSION}

All bee samples revealed the presence of analyzed metals: $\mathrm{Cu}, \mathrm{Cr}, \mathrm{Zn}, \mathrm{Mn}, \mathrm{Fe}$, and their contents depended on the sampling period (Table 1). This is a good indication, that testifies to the fact that bees are good bioindicators of environmental contamination with metals.

The $\mathrm{Cu}$ content ranged from 13.7 to 34.6 $\mathrm{mg} \cdot \mathrm{kg}^{-1} \mathrm{DM}$ (mean $19.4 \mathrm{mg} \cdot \mathrm{kg}^{-1} \mathrm{DM}$ ); the lowest content of $\mathrm{Cu}$ in the samples of test bees were recorded in March with an average of $16.3 \mathrm{mg} \cdot \mathrm{kg}^{-1}$ DM. The largest for bees collected in summer (June) with the average content of $25.2 \mathrm{mg} \cdot \mathrm{kg}^{-1}$ DM. Confronting these values with literature data, it is clear that they are consistent with those reported by Roman [2003]: $\mathrm{Cu}$ content in bees from urban areas was $23.3 \mathrm{mg} \cdot \mathrm{kg}^{-1} \mathrm{DM}$, whilst from farmlands and forests $22.0 \mathrm{mg} \cdot \mathrm{kg}^{-1} \mathrm{DM}$. Similar results were also obtained by SzymanowskaBielawska [1981]: $25.4 \mathrm{mg} \cdot \mathrm{kg}^{-1} \mathrm{DM}$. Zhelyazkova [2012] showed copper levels in samples of test bees from the area of the bulgarian city Stara Zagora, in the range of $15.75-21.19 \mathrm{mg} \cdot \mathrm{kg}^{-1}$ DM. Studies conducted in Serbia showed similar concentration of $\mathrm{Cu}$, which ranged within 11.8$29.2 \mathrm{mg} \cdot \mathrm{kg}^{-1} \mathrm{DM}$, at average level of $21 \mathrm{mg} \cdot \mathrm{kg}^{-1}$ DM [Zarić et al. 2016]. Copper is an element that supports many processes in living organisms.
A large load of copper is introduced along with dust from coal combustion and traffic. The presence of $\mathrm{Cu}$ in urban areas should be explained by anthropogenic and industrial activity. The continuous brakes use in the urban areas is indeed the main source of copper in urban environments $[\mathrm{Li}$ et al. 2001]. Agricultural areas, where pesticides as well as fertilizers and organic are used, are also the threat.

Regardless of the bee sampling period, $\mathrm{Cr}$ showed the lowest contents in relation to the investigated metals. It ranged from 2.4 to 3.5 $\mathrm{mg} \cdot \mathrm{kg}^{-1} \mathrm{DM}$ (mean $2.8 \mathrm{mg} \cdot \mathrm{kg}^{-1} \mathrm{DM}$ ). There has been the highest average concentration of $\mathrm{Cr}$ in bees collected in June (mean $3.1 \mathrm{mg} \cdot \mathrm{kg}^{-1} \mathrm{DM}$ ), while the lowest content was recorded in September (mean $2.5 \mathrm{mg} \cdot \mathrm{kg}^{-1} \mathrm{DM}$ ). Similar dependence was found by Perugini et al. [2011] in the study carried out in Italy within urban and rural areas. The most of $\mathrm{Cr}$ in bee organisms was found in summer and the least in autumn, but at much lower average contents of $0.97 \mathrm{mg} \cdot \mathrm{kg}^{-1} \mathrm{DM}$ and 0.33 $\mathrm{mg} \cdot \mathrm{kg}^{-1} \mathrm{DM}$. Szymanowska-Bielawska [1981] in their study reported the $\mathrm{Cr}$ content equal to 0.97 $\mathrm{mg} \cdot \mathrm{kg}^{-1} \mathrm{DM}$. Lower values of $\mathrm{Cr}$ found by Roman [2003]: an average of $0.24 \mathrm{mg} \cdot \mathrm{kg}^{-1} \mathrm{DM}$ from the airport area and agro-forestry area of $0.19 \mathrm{mg} \cdot \mathrm{kg}^{-1}$ DM. A study performed by Eremia et al. [2010]

Table 1. Contents of studied metals in honeybee (Apis mellifera L.) organism

\begin{tabular}{|c|c|c|c|c|c|c|}
\hline \multirow{3}{*}{ Metal/ month } & $\mathrm{n}$ & $\mathrm{Cu}$ & $\mathrm{Cr}$ & $\mathrm{Zn}$ & $\mathrm{Mn}$ & $\mathrm{Fe}$ \\
\cline { 2 - 7 } & \multicolumn{7}{|c|}{$\left[\mathrm{mg} \cdot \mathrm{kg}^{-1} \mathrm{DM}\right]$} \\
\hline \multirow{3}{*}{ March } & 1 & 15.3 & 2.7 & 57.3 & 24.1 & 150.2 \\
\cline { 2 - 7 } & 2 & 15.6 & 2.6 & 57.6 & 21.3 & 135.1 \\
\cline { 2 - 7 } & 3 & 14.9 & 2.7 & 57.8 & 31.4 & 132.6 \\
\cline { 2 - 7 } & 4 & 19.2 & 2.8 & 54.6 & 29.5 & 144.4 \\
\hline \multirow{4}{*}{ June } & 1 & 34.6 & 2.8 & 85.7 & 51.1 & 232.4 \\
\cline { 2 - 7 } & 2 & 24.3 & 3.5 & 81.2 & 52.5 & 317.1 \\
\cline { 2 - 7 } & 3 & 22.1 & 3.1 & 78.8 & 53.2 & 198.7 \\
\cline { 2 - 7 } September & 4 & 19.6 & 2.9 & 72.5 & 40.5 & 172.1 \\
\hline & 1 & 15.5 & 2.7 & 66.1 & 45.9 & 152.1 \\
\cline { 2 - 7 } & 2 & 13.7 & 2.5 & 60.9 & 35.2 & 142.3 \\
\cline { 2 - 7 } & 3 & 23.4 & 2.4 & 79.6 & 64.2 & 204.6 \\
\cline { 2 - 7 } & 4 & 14.9 & 2.5 & 63.8 & 37.9 & 144.9 \\
\hline \multicolumn{7}{|c|}{ General statistics } \\
\hline Minimum & 13.7 & 2.4 & 54.6 & 21.3 & 132.6 \\
\hline Maximum & 34.6 & 3.5 & 85.7 & 64.3 & 317.2 \\
\hline Arithmetic mean & 19.4 & 2.8 & 67.9 & 40.5 & 177.2 \\
\hline Median & 17.4 & 2.7 & 64.9 & 39.2 & 151.2 \\
\hline Standard deviation & 6.01 & 0.29 & 11.02 & 13.08 & 54.20 \\
\hline
\end{tabular}


showed that the concentration of $\mathrm{Cr}$ in the samples of studied bees from urban area in Moldova amounted to an average of $2 \mathrm{mg} \cdot \mathrm{kg}^{-1} \mathrm{DM}$.

The concentration of $\mathrm{Cr}$ revealed in our study showed alarming quantities. Increased $\mathrm{Cr}$ content in bee organisms may be related to the chemical composition of the wood impregnation agents, which are used to paint hives. Kalnins and Detroy [1984] studied the effect of impregnation on the concentrations of $\mathrm{As}, \mathrm{Cr}$, and $\mathrm{Cu}$ in bee tissues. They found significantly increased concentrations of $\mathrm{As}$ and $\mathrm{Cr}$ in bees. Another source of chromium contamination in bee organisms is anthropogenic activity. Chromium presence in environment originates from natural and anthropogenic sources, but because of intensive human activity, natural sources paly symbolic role as $60 \%$ to $70 \%$ of this element comes from anthropogenic sources. According to Perugini et al. [2011] Cr is a major problem in terms of pollution of the world. The chromium sources, which are dangerous for the environment, come from the metallurgical and chemical industry, the electroplating or the production of stainless steel alloys, production of fungicides, and printing and graphics plants. Many products for daily use, such as cement, dyes, and detergents, contain $\mathrm{Cr}$. Relatively high $\mathrm{Cr}$ contents in the studied organisms of bees could be affected by print shops, factory of jigs and fixtures, as well as allotments, in which fungicides have been probably used. Chromium gets into the environment, especially to the atmosphere, also from the coal burning, which undoubtedly influenced the increased level of $\mathrm{Cr}$ in the bodies of bees.

The $\mathrm{Zn}$ content ranged from 57.2 to 85.6 $\mathrm{mg} \cdot \mathrm{kg}^{-1} \mathrm{DM}$ (mean $67.9 \mathrm{mg} \cdot \mathrm{kg}^{-1} \mathrm{DM}$ ), with the lowest concentration of $\mathrm{Zn}$ visible in March, an average of $56.8 \mathrm{mg} \cdot \mathrm{kg}^{-1} \mathrm{DM}$, while the largest recorded for bees collected in June, the average content was $79.6 \mathrm{mg} \cdot \mathrm{kg}^{-1} \mathrm{DM}$. These data are similar to those obtained by Eremia et al. [2010]: an average of $66.13 \mathrm{mg} \cdot \mathrm{kg}^{-1} \mathrm{DM}$. In turn, the publication by Zhelyazkova [2012] showed levels of zinc in the studied bees about $58.23-111.09 \mathrm{mg} \cdot \mathrm{kg}^{-1} \mathrm{DM}$. Study upon bioindication conducted by Zarić et al. [2016], revealed $\mathrm{Zn}$ content of $65-156 \mathrm{mg} \cdot \mathrm{kg}^{-1}$ $\mathrm{DM}$ at average of $100 \mathrm{mg} \cdot \mathrm{kg}^{-1} \mathrm{DM}$. Zinc in the study area may origin from the printing factory, plastics industry, and the use of plant protection products, as well as fertilizers from the nearby allotments. Significant threat is also the coal burning. Curzydło [1989] believes that Zn near transport routes mainly comes from its content in motor oil and from frequent and sudden braking, which was confirmed by Garty et al. [1996].

Manganese, which was the next investigated metal in the study, is an essential element for living organisms, but its high doses at low $\mathrm{pH}$ are toxic. The Mn content varied from 21.3 to $64.3 \mathrm{mg} \cdot \mathrm{kg}^{-1} \mathrm{DM}$ (mean $40.5 \mathrm{mg} \cdot \mathrm{kg}^{-1} \mathrm{DM}$ ), the highest concentration of $\mathrm{Mn}$ was found in the bee organisms collected in June, at average of $49.4 \mathrm{mg} \cdot \mathrm{kg}^{-1} \mathrm{DM}$, while the lowest for bees collected in March, with the average content of $26.6 \mathrm{mg} \cdot \mathrm{kg}^{-1} \mathrm{DM}$. A study carried out by Zhelyazkova [2012] in the vicinity of Stara Zagora city showed levels of $\mathrm{Mn}$ in tested bees of about 43-114 $\mathrm{mg} \cdot \mathrm{kg}^{-1} \mathrm{DM}$ and in Serbia 34-90 $\mathrm{mg} \cdot \mathrm{kg}^{-1}$ DM [Zarić et al. 2016]. The source of Mn presence in the surroundings of apiary, from which the bees were collected to tests, can probably be a transport and coal combustion.

Among studied elements, the highest values were obtained for $\mathrm{Fe}$, which ranged from 132.6 to $317.2 \mathrm{mg} \cdot \mathrm{kg}^{-1} \mathrm{DM}$ (mean $177.2 \mathrm{mg} \cdot \mathrm{kg}^{-1} \mathrm{DM}$ ). The lowest concentration of Fe was recorded in organisms of bees collected in March with an average of $140.6 \mathrm{mg} \cdot \mathrm{kg}^{-1} \mathrm{DM}$. The highest concentrations were found in the case of bees collected in June, at the average content of $229.9 \mathrm{mg} \cdot \mathrm{kg}^{-1} \mathrm{DM}$. It should be noted that available literature reports $\mathrm{Fe}$ contents similar or slightly lower. In three Bulgarian regions, it amounted to $88-102 \mathrm{mg} \cdot \mathrm{kg}^{-1} \mathrm{DM}$ [Zhelyazkova 2012], in Moldova $116 \mathrm{mg} \cdot \mathrm{kg}^{-1} \mathrm{DM}$ [Eremia et al. 2010], and Serbia 101-421 $\mathrm{mg} \cdot \mathrm{kg}^{-1}$ DM [Zarić et al. 2016]. Although Fe is an essential element for living organisms, it can be toxic at higher concentrations. Iron is one of the main elements of the earth's crust, making up 5\% of its composition. In the soil solution, it occurs in the form of simple as well as complex ions. Iron is one of the most mobile elements in the soil. The easy way it gets into the water. In the short distance from the apiary, there is a small river, from which the bees collect water, which may explain situation in Bialystok city. Coal combustion can also be the source of $\mathrm{Fe}$ in city environment of Bialystok.

The calculations showed no statistically significant differences between the contents of metals in different research periods (March, June, September). The lack of differences was demonstrated by the analysis of Wald-Wolfowitz, Kolmogorov-Smirnov, and Mann-Whitney U statistical testing results. 
The Spearman correlation analysis (Table 2) revealed quite high level of dependence (from $r$ $=0.55$ up to $\mathrm{r}=0.90$ ) between individual metals, except from $\mathrm{Cr}$, which may prove their common source (origin), i.e. air, soil, plants, or water. Most of studied metals show a strong correlation with $\mathrm{Fe}$ (from $\mathrm{r}=0.83$ to $\mathrm{r}=0.85$ ). Numerous studies upon metal migration within the soil environment indicate their strong associations with $\mathrm{Fe}$ and $\mathrm{Mn}$ oxides due to occurring sorption processes that are usually complex. These mechanisms seem to confirm the thesis of a common origin of studied metals in organisms of tested bees, to which they may penetrate due to a contact with dust in the air. In the case of $\mathrm{Cr}$, that had the least association with other metals (from $r=0.24$ to $r=0.55$ ), it can presumed its different origin, which was confirmed by earlier considerations on impregnation of hive walls. The impregnation agent can be the main $\mathrm{Cr}$ source penetrating bee's organisms due to their direct contact with hive material and through the air.

The performed study revealed that the metals in organism of honeybee (Apis mellifera L.) were accumulated in the order of $\mathrm{Cr}<\mathrm{Cu}<\mathrm{Mn}<\mathrm{Zn}<\mathrm{Fe}$ in all research periods. Contents of $\mathrm{Cu}, \mathrm{Zn}, \mathrm{Mn}$, and $\mathrm{Fe}$ in the test samples of bees were consistent with the results of other authors, while in contrast, $\mathrm{Cr}$ was at higher level. The range of studied metals accumulation was dependent on the sampling period. The highest content was recorded in June, when bees showed the highest activity, collected pollen and nectar, which contributed to the greater exposure to pollutants in the environment. According to Lambert et al. [2012], Satta et al. [2012] weather conditions also affect the content of metals in the bees bodies, dry weather and higher temperatures cause higher amounts of metals, what was confirmed by the research.

Data obtained in this study do not allow any detailed conclusions on the degree of $\mathrm{Cr}, \mathrm{Cu}$, $\mathrm{Zn}, \mathrm{Mn}$ and Fe bioaccumulation in the environment, but they demonstrated the ability of bees to detect concentrations of metals. Bees are good bioindicators because of the ease of sampling, no need for complicated and expensive technical facilities and accumulate contaminants from the air, soil and water. A network of apiaries located in contaminated areas can provide data for monitoring of toxic metals emissions from point and diffuse sources. Bees can be an attractive way of anthropogenic changes assessment over long periods. Bees are one of the most important ele-
Table 2. Spearman correlation coefficients (r) for achieved dependencies $(\mathrm{p}<0.05)$

\begin{tabular}{|c|c|c|c|c|c|}
\hline Component & $\mathrm{Cu}$ & $\mathrm{Cr}$ & $\mathrm{Zn}$ & $\mathrm{Mn}$ & $\mathrm{Fe}$ \\
\hline $\mathrm{Cu}$ & 1.00 & 0.55 & 0.71 & 0.64 & 0.83 \\
\hline $\mathrm{Cr}$ & 0.55 & 1.00 & 0.30 & 0.24 & 0.46 \\
\hline $\mathrm{Zn}$ & 0.71 & 0.30 & 1.00 & 0.90 & 0.85 \\
\hline $\mathrm{Mn}$ & 0.64 & 0.24 & 0.90 & 1.00 & 0.83 \\
\hline $\mathrm{Fe}$ & 0.83 & 0.46 & 0.85 & 0.83 & 1.00 \\
\hline
\end{tabular}

ments of agriculture, because they are one of the most widespread and effective pollinators. For this reason, the effects of pollution on the bees are constantly growing; bee populations may be thus threatened by human activities.

\section{CONCLUSIONS}

1. In all bee samples, presence of $\mathrm{Cu}, \mathrm{Cr} \mathrm{Zn}, \mathrm{Mn}$, and $\mathrm{Fe}$ was recorded.

2. The main sources of studied metals in bee samples seem to be motorization, industry, and municipal economy within the urban area. Statistical calculations showed a common origin of majority of studied metals.

3. Elevated $\mathrm{Cr}$ concentration in bee organisms can be an effect of this element presence in environment (soil, water, plants, pollen), as well as impregnation agent applied to protect wooden hive walls. The analyses allowed for univocal estimation of chromium in bee samples.

4. The study revealed the seasonal variability of metals in bee samples. The highest contents of studied elements were recorded in summer, which was associated with great activity of bees that time. However, the seasonal differences were not characterized by statistical significance.

5. Bee studies for metals contents can be an important element of a bio-monitoring of changing natural environment as a consequence of anthropogenic activity.

6. The network of apiaries located in urban areas may provide data for monitoring the emission of metals from pollution sources.

\section{Acknowledgements}

The research was carried out as part of the work No. S/WBiIŚ/3/2014 and financed from the resources for education by The Ministry of Science and Higher Education. 


\section{REFERENCES}

1. Bojakowska I. 1995. Wpływ odprowadzania ścieków na akumulację metali ciężkich w osadach wybranych rzek Polski. Państwowy Instytut Geologiczny, Warszawa.

2. Buczek K., Chełmiński M., Kauko L. 2008. Immunotoksyczne i immunosupresyjne działanie środowiska na organizm pszczoły miodnej (Apis mellifera L.), Annales Universitatis Mariae CurieSkłodowska Lublin - Polonia, 21-26.

3. Celli G., Maccagnani B. 2003. Honey bees as bioindicators of environmental pollution., Bulletin of Insectology, 137-139.

4. Curzydło J. 1989. Ołów i cynk w roślinach i glebach w sąsiedztwie drogowych szlaków komunikacyjnych. Rozpr. Habil. nr 127, Zesz. Nauk., AR, Kraków.

5. Eremia N., Dabija T., Dodon I. 2010. Micro- and macroelements content in soil, plants nectaro pollenifer leaves, pollen and bees body. Animal Science and Biotechnologies, 43.

6. Garty J., Kauppi M., Kauppi A. 1996. Accumulaction of airborne elements from vehicles in transplanted lichens in urban sites, J. Environ. Qual., 25, 265-272.

7. Kabata-Pendias A., Pendias H. 1999. Biogeochemia pierwiastków śladowych. PWN, Warszawa.

8. Kalnins A.A., Detroy B.F.1984. Effect of wood preservative treatment of beehives on honey bees and hive products. Journal of Agricultural and Food Chemistry, 31, 1176-1180.

9. Kaniuczak J., Trąba G., Godzisz J. 2003. Zawartość ołowiu i kadmu w glebach i roślinach przy wybranych szlakach komunikacyjnych rejonu zamojskiego. Zesz. Probl. Post. Nauk Rol., 493, I, 193-199.

10. Klavins M., Briede A., Rodi V., Kokorite I., Parele E., Klavins I. 2000. Heavy metals in rivers of Latvia. Sci. Total. Environ., 262, 175-183.

11. Li X., Poon C., Liu PS. 2001. Heavy metal contamination of urban soils and street dusts in Hong Kong. Appl Geochem 16(11-12), 1361-1368.

12. Liu J., Li Y., Zhang B., Cao J., Cao Z., Domagalski J. 2009. Ecological risk of heavy metals in sediments of the Luan River source water. Ecotoxicology. 18, 748-758.

13. Madras-Majewska B., Jasiński Z. 2003. Lead content of bees, broad and bee products from different regions of Poland. Journal of Apicultural Science, 47-55.

14. Niedźwiecki E., Protasowicki M., Kujawa D., Niedźwiecka D. 2000. Zawartość kadmu i ołowiu w pyle opadowym w obrębie aglomeracji szczecińskiej. In: Kadm w środowisku - problemy ekologiczne i metodyczne, Zesz. Nauk. Kom. „Człowiek i środowisko”, PAN, 26, 201-207.

15. Perugini M., Manera M, Grotta L, Cesarina Abete M., Tarasco R., Amorena M. 2011. Heavy Metal $(\mathrm{Hg}, \mathrm{Cr}, \mathrm{Cd}$, and $\mathrm{Pb}$ ) Contamination in urban areas and wildlife reserves: honeybees as bioindicator. Biol Trace Elem Res, 140, 170-176.

16. Porrini C., Sabatini A.G., Girotti S, Ghini S., Medrzycki P., Grillenzoni F., Bortolotti L. 2003. Honey bees and bee products as monitors of the environmental contamination, Apiacta 63-70.

17. Roman A. 2003. Wpływ stanu toksykologicznego miodu na poziom kumulacji wybranych pierwiastkow śladowych w organizmie pszczoły miodnej (Apis mellifera L), Acta agrophysica, 1(2), 295-300.

18. Roman A. 2010. Level of copper, selenium, lead, and cadmium in forager bees. Polish Journal of Environmental Studies, 19, 3, 663-669.

19. Ruschioni S., Riolo P., Minuz R.L., Stefano M., Cannella M., Prorrini C., Isidoro N. 2013. Biomonitoring with honeybees of heavy metals and pesticides in nature reserves of the Marche Region (Italy). Biol Trace Elem Res, 226-233.

20. Sadeghi A., Mozafari A., Bahmani R., Shokri K. 2012 Use of honeybees as bio-indicators of environmental pollution in the Kurdistan province of Iran., Journal of Apicultural Science, 83-88.

21. Skorbiłowicz E. 2012. Studia nad rozmieszczeniem niektórych metali w środowisku wodnym zlewni górnej Narwi. Rozp nauk nr 222. Białystok: Oficyna Wydawnicza Politechniki Białostockiej, pp. 212.

22. Steen J.J.N. van der, de Kraker J., Grotenhuis T. 2012. Spatial and temporal variation pszczół miodnych of metal concentrations in adult honeybees (Apis mellifera L.), Environ Monit Assess, 184, 4119-4126.

23. Steen J.J.M. van der, Cornelissen B., Blacquière T., Pijnenburg J.E.M.L., Severijnen M. 2016. Think regionally, act locally: metals in honeybee workers in the Netherlands (surveillance study 2008), Environ Monit Assess 188, 463.

24. Szymanowska-Bielawska K. 1981. Content of mineral compounds in bee worker body Apis mellifica L., Apicultural Scientific Exercise Books, 25, 43.

25. Zarić N.M., Ilijević K., Stanisavljević L, Grźetić I. 2016. Metal concentrations around thermal power plants, rural and urban areas using honeybees (Apis mellifera L.) as bioindicators. Int. J. Environ. Sci. Technol., 13, 413-422.

26. Zhelyazkova I. 2012. Honeybees - bioindicators for environmental quality. Bulgarian Journal of Agricultural Science, 18(3), 435-442. 